\title{
X-ray tomography as a tool for detailed anatomical analysis
}

Jan VAN DEN BULCKE ${ }^{1 *}$, Matthieu BOONE ${ }^{2}$, Joris VAN ACKER ${ }^{1}$, Marc STEVENS ${ }^{1}$, LUC VAN HOOREBEKE ${ }^{2}$

${ }^{1}$ Laboratory of Wood Technology, Faculty of Bioscience Engineering, Ghent University, Coupure Links 653, 9000 Ghent, Belgium

${ }^{2}$ Department for Subatomic and Radiation Physics, Faculty of Sciences, Ghent University, Proeftuinstraat 86, 9000 Gent, Belgium

*e-mail: Jan.VandenBulcke@UGent.be;

postal address: Ghent University Laboratory of Wood Technology

Coupure Links 653 9000 Ghent Belgium

tel: + 0032 (0)9 26461 24; fax: + 0032 (0)9 2646233

Running head: X-ray tomography for wood analysis

Keywords: X-ray CT / wood / anatomy / image processing

Cite as:

Van den Bulcke, J., Boone, M., Van Acker, J., Stevens, M., Van Hoorebeke, L. (2009c). X-ray tomography as a tool for detailed anatomical analysis. Annals of Forest Science 66(5): 508.

DOI: $10.1051 /$ forest/2009033 


\begin{abstract}
38 Abstract
39

40 * Wood identification, anatomical examination and retrieval of quantitative

41 information are important aspects of many research disciplines.

42 Conventional light microscopy with a camera and (semi-)automatic image

43 analysis software is an often used methodology for these purposes. More

44 advanced techniques such as fluorescence, scanning electron,

45 transmission electron, confocal laser scanning and atomic force

46 microscopy are also part of the toolset answering to the need for detailed 47 imaging.

48 * Fast, non-destructive visualization in three dimensions with high 49 resolution combined with a broad field of view is sought-after, especially in 50 combination with flexible software.

51 * A highly advanced supplement to the existing techniques, namely X-ray 52 sub-micron tomography, meets these requirements. It enables the 53 researcher to visualize the material with a voxel size approaching $<1 \mu \mathrm{m}$ 54 for small samples $(<1 \mathrm{~mm})$. Furthermore, with tailor-made processing 55 software quantitative data about the wood in two and three dimensions 56 can be obtained. Examples of visualization and analysis of four wood 57 species are given in this paper, focusing on the opportunities of 58 tomography at micron and sub-micron resolution.

59 * X-ray computed tomography offers many possibilities for material 60 research in general and wood science in specific, as a qualitative as well 61 as a quantitative technique.
\end{abstract}

62 


\section{Introduction}

Wood identification as well as quantification of anatomical features is important for many disciplines such as tree physiology (Fonti et al., 2007), wood technology (Makinen et al., 2008), archaeology (Philippe and Bamford, 2008), forensics (Coyle et al., 2001), etc. Identification relies on the macroscopic appearance and the characteristics revealed under a microscope. Mainly, examining axial, tangential and radial microtome sections is necessary for correct determination. Semi-automated image analysis of these sections leads to quantitative data such as porosity, fibre length, vessel diameter, cell wall thickness etc. The conventional approach consists of a microtome, a light microscope with a camera mounted on top and image analysis software. Modern techniques can assist in determination and characterization of wood species: SEM (Scanning Electron Microscopy), TEM (Transmission Electron Microscopy), AFM (Atomic Force Microscopy), CSLM (Confocal Scanning Laser Microscopy) etc. Yet most of the time, obtaining quantitative information is labour- and time intensive. In addition to aforementioned techniques, X-ray tomography is explored in this paper as a tool for detailed anatomical research. It is a technique used in several research disciplines such as medicine (Fu and Kuduvalli, 2008), soil science (Taina et al., 2008), hydrology (Wildenschild et al., 2002), entomology (Fuchs et al., 2004), plant physiology (Lee and Kim, 2008) and material science (Cnudde and Jacobs, 2004) to name only a few. Even in wood science, its possibilities are employed. In its two dimensional form, X-ray analysis is already used for densitometry (Knapic et al., 2007; Macchioni et al., 2007; Tomazello et al., 2008). X-ray computed tomography in three dimensions is utilized for the analysis of low-density fibreboard under compression (Badel et al., 2008), study of wood-plastic composites (Wang et al., 2007), detection of organosilicon compounds (De Vetter et al., 2006), microstructure analysis of spruce wood (Trtik et al., 2007) and quantitative wood anatomy (Steppe et al., 2004).

The purpose of this article is to illustrate the power of X-ray computed tomography as a tool for both descriptive and quantitative wood identification and anatomy to resolve details on three-dimensional reconstructions with near sub-micron scale without destruction or labourintensive sample preparation. This non-destructiveness has the advantage to visualize the object's original structure, without cell damage or artefacts during sample preparation. What is more, the flexible set-up allows scanning of objects of diverse dimensions with a sufficient field of view resulting in large high detailed volumes. As such, the sample can be examined in all possible directions, making fast evaluation possible. Parallax effects as explained by Park and Telewski (1993) cause no problems and any manipulation of the virtual object is possible. The technique is illustrated for four wood species using several selfexplanatory images and calculations of cell wall thickness and cell lumen 
109 size on $2 \mathrm{D}$ slices with standard $M A T L A B \AA$ algorithms. To highlight the 110 possibility of 3D quantitative wood anatomy, a subvolume of a data stack 111 is processed. Special software (Morpho+; Vlassenbroeck et al., 2007) for

\section{Materials and methods}

The four wood species used for X-ray analysis are Scots pine (Pinus silvestris L. - earlywood and latewood), beech (Fagus sylvatica L.), movingui (Disthemonanthus benthamianus Baill.) and afzelia (Afzelia bipindensis Harms). These species represent hard- and softwood as well as temperate and tropical wood species. Pine sapwood and beech are often used in European standards whereas movingui and afzelia are durable tropical species on the market (e.g. in Belgium). Five samples, two for pine (early- and latewood) and one per other wood species, were prepared by slicing a thin wood section of a larger block and subdividing it with a microtome or scalpel in needle-shaped specimens (Fig. 1).

Fig. 1.

The tip of this needle-shaped wood sample, measuring approximately one $\mathrm{mm}^{3}$ was scanned using the X-ray equipment built at the Centre for X-ray Tomography at Ghent University (UGCT, http://www.ugct.ugent.be). This is a state-of-the-art scanner (Masschaele et al., 2007), highly flexible, with in-house developed software for scanner control, sample reconstruction, analysis and visualization. The X-ray source, a nano-focus tube, can reach a focal spot size down to one $\mu \mathrm{m}$. All samples were scanned at an average voltage of $50 \mathrm{kV}$ and a current of $40 \mu \mathrm{A}$ with a total scan time of approximately 2 hours. A rotation step size of $0.36^{\circ}$ was used. Reconstruction took 20 min with Octopus, a server/client tomography reconstruction package for parallel and cone beam geometry (Vlassenbroeck et al., 2007). With the described set-up submicron resolution can be reached, resulting in scans with voxels sizing approximately $0.7 \times 0.7 \times 0.7 \mu \mathrm{m}$. The small voxel size gave a clear view on anatomical features. Subvolumes of these reconstructed slices were further manipulated with MATLAB $®$ and Morpho+ (Vlassenbroeck et al., 2007). First, the slices were pre-processed aiming at noise removal and image enhancement. This included histogram equalization to transform the values of the greyscale images such that contrast was improved. Subsequently the images were binarized using the topological derivative of Larrabide (2008). Finally, slices were despeckled by removal of small isolated pixel islands. For the pine early- and latewood specimen, better results were obtained when images were denoised using the non-linear diifusion technique as outlined by D'Almeida (non-linear diffusion toolbox by Frederico D'Almeida). Subsequently, once denoised images were available, wood parameters such as cell wall thickness and cell lumen size 
could be calculated on 2D slices and labelling of a subvolume of pine (Van den Bulcke et al., 2008) could be performed in three dimensions. Cell lumen sizes were determined via marker-based segmentation. This procedure starts with determination of the local maxima of the distance transform of the image, as such representing the centres of the cell lumens. Application of the watershed algorithm with these local maxima as markers correctly separated cells formerly connected though open pits. In fact, this is an automatic version of the technique described in Reme and Helle (2002) for pit removal. Manual editing was necessary to remove ray cells from analysis and to undo incorrect segmentation, but analysis is quite fast, naturally depending on the quality of segmentation. Calculation of cell wall thickness was accomplished by using the distance transform of the skeletonised image. The cell wall thickness (CW) then equals (1):

$$
\begin{aligned}
& \text { In addition, to exemplify the practical use of X-ray computed tomography } \\
& \text { in wood research, six pine latewood volumes, sampled from pith to bark, } \\
& \text { were scanned. A modified bronnikov algorithm (Boone et al., 2009) was } \\
& \text { employed for phase-contrast imaging. Figure } 2 \text { shows a slice through one } \\
& \text { of the two scanned stacks consisting of three of samples separated by an } \\
& \text { adhesive tape. The voxel size was } 1.68 \mu \mathrm{m} \text { and samples measured } \\
& \text { approximately } 1.6 \times 1.8 \times 1.1 \mathrm{~mm} \text {. }
\end{aligned}
$$

\section{Fig. 2.}

For correct analysis, rotation of the samples was obligatory. Once rotated, preprocessing included smoothing, noise removal and automated greyscale thresholding. Analysis of several 2D sections per sample resulted in mean values for cell perimeter and cell wall thickness and a profile in function of age.

All images were rendered with VGStudio MAX®, MATLAB®, Octopus 3D Viewer and Drishti (Limaye, 2006).

\section{Results and discussion}


197 For each wood species, several images will illustrate the anatomy. A 3D 198 reconstruction gives an overview of the scan, cross-sectional views in 199 axial, radial and tangential direction are given similar to conventional 200 cross-sectional views by Wagenführ and Schreiber (1989), IAWA list of microscopic features for hardwood identification (IAWA Committee et al., 1989), Schweingruber (1990), IAWA list of microscopic features for softwood identification (IAWA Committee et al., 2004) and Wagenführ (2007). Characteristics of the wood are calculated on 2D sections and a 205 3D subvolume is used for 3D analysis. Finally, the brief study of six pine 206 latewood samples further exemplifies the practical use of X-ray tomography in wood research.

\subsection{Microscopic features}

Below follows an overview of the characteristics of the wood species under study.

\section{Pinus silvestris $L$.}

Scots pine, member of the Pinaceae family, is characterized by its homogeneous anatomy with tracheids as the main structural element and with a minor share of resin channels. Early- (EW) and latewood (LW) are clearly different in tracheid wall thickness and lumen size. Pitting of radial walls of tracheids is predominantly uniseriate. Wood rays are heterocellular, composed of ray parenchyma and ray tracheids with dentate thickenings and small pits. Cross-field pitting is fenestriform, on average one pit per cross-field. These microscopic features can be visualized on $3 \mathrm{D}$ reconstructions of pine given in Fig. 3 and several views through the volume.

Fig. 3.

\section{Fagus sylvatica L.}

Beech, member of the Fagaceae family, is a temperate hardwood species with a typical diffuse porous structure. The vessels are scattered and only reach small diameters. Wood rays can be subdivided in large and small individuals. Fibres have a relatively small lumen and a moderate thick wall. Vessel ray pitting is horizontal and have much reduced borders (predominantly scalariform). The compilation of images in Fig. 4 illustrates several of these characteristics.

\section{Fig. 4.}

Disthemonanthus benthamianus Baill. 
243 Movingui, member of the Leguminosae-Caesalpinioideae family, is a 244 diffuse-porous tropical hardwood, with little but large vessels and fibres.

245 Parenchyma is apotracheal-terminal or paratracheal-aliform.

246 Heterogeneous wood rays are small and not very high. The presence of

247 silicon in heartwood is not unusual. Fig. 5 illustrates the different

Fig. 5.

\section{Afzelia bipindensis Harms}

Afzelia, also a member of the Leguminosae-Caesalpinioideae family, is a diffuse-porous tropical hardwood, with little but large vessels and thick fibres. Parenchyma is paratracheal aliform. Wood rays are small and not very high. Vessel perforation is simple. Crystals are abundantly present. The rendered volumes in Fig. 6 exemplify the wood anatomy.

\section{Fig. 6.}

\subsection{Quantitative analysis}

Image processing of large anisotropic volumes is a difficult task. Yet, wood consists of a 3D structure that can be described effectively with 2D sections. Therefore, for the determination of parameters such as cell (lumen) size and cell wall thickness, a 2D section is sufficient. The procedure is very straightforward once a noise-free image is obtained. Pre-processing included selection of the tissue of interest, histogram equalization, standard noise filtering and image binarization. As an example, Fig. 7 illustrates the difference between the original images with noise, the noise-free (MATLAB $\left.{ }^{\circledR}\right)$ and segmented (Morpho+) images for the four wood species. The segmented image can be used for measuring cell properties; in fact, the segmented images in Figure 6a are colourcoded according to their lumen size.

\section{Fig. 7.}

Via marker-based watershed image segmentation cell lumen size was determined. Cell lumen size frequencies are given in the line plots in Fig. 8 for the four wood species. The vessel sizes of afzelia and movingui are not displayed because of their large size and low frequency. It should be mentioned that, considering the natural variability of wood anatomy, these results are not representative of the four species.

Fig. 8. 
288 The difference in lumen size between early- and latewood tracheids is 289 clear. Larger structures such as rays were labelled as well and manually 290 removed from the analysis, but could be filtered (semi-)automatically using shape descriptors, e.g. by their elongated form. Dimensions can be used to split up vessels and fibres. It is clear that by proper demarcation of the different zones, the different tissue sizes can be determined. Once such a segmented and labelled dataset is available, calculations of a whole set of properties is straightforward. Cell wall thickness is calculated from these segmented images by skeletonization (Fig. 9). Results for pine are in agreement with the data in literature (Reme and Helle, 2002) while for the other species the reader is referred to Wagenführ and Schreiber (1989) and Wagenführ (2007).

Fig. 9.

As an example of $3 D$ analysis performed in $M A T L A B \AA$, the pine earlywood data stack is used. Optimal preprocessing of the stack of the original 2D sections included histogram equalization, noise removal by nonlinear image diffusion and image binarization using the topological derivative. The resulting noise-free, segmented subvolume is given in Fig. $10 \mathrm{a}$. Figure $10 \mathrm{~b}$ and $10 \mathrm{c}$ show the limits of resolution by displaying a three dimensional rendering and a $2 \mathrm{D}$ slice of pitting.

Fig. 10.

Three-dimensional reconstruction of a reduced region of interest based on watershed segmentation of the noise-free volume gives a view on the labelling of the different colour-shuffled tracheid lumens. The original binarized cell wall is visible as the greyish substance in-between in Figure 11a. This labelled volume can serve as the basis for calculation of length and shape of single elements. The limits of resolution permit to visualize individual pits as illustrated by Figure 11b. If 3D cell characteristics are desired, subtracting the skeletonised cell walls from the cell wall volume leads to the separated structures for volumetric analysis. However, whereas 2D analysis is fast, easy to correct and accurate 3D analysis of large volumes is much more difficult. Especially for hardwood species such analysis will pose problems and should be performed on isolated anatomical regions.

\subsection{Analysis from pith to bark}

A pith to bark analysis was performed for six pine latewood samples. Figure 11 illustrates the rendered volumes and the results of cell wall thickness and total cell perimeter measurements. These data are roughly in agreement with the data presented by Reme and Helle (2002). 
333 Obviously, juvenile wood has thinner walls and smaller cells in contrast 334 with mature wood. It should be stressed that these data are not an in335 depth study of the changing latewood characteristics of Scots pine yet a 336 proof of concept of the use of the X-ray computed modality presented in 337 this paper.

338

\section{Conclusions}

X-ray sub-micron tomography has been shown here to be a powerful image acquisition technique for wood research. The level of detail suffices for descriptive and quantitative anatomical analysis as exemplified in this paper. Very small samples can be scanned at very high resolution, making it appropriate for forensics and analysis of cultural heritage. Its nondestructiveness is an advantage when dealing with valuable material compared to classical methods, entailing the absence of preparation artefacts as well. Furthermore, volume mosaicing will enable the reconstruction of larger samples at a high level of detail, only limited by data handling and storage. In addition, a factor not to be neglected is the educational value of $3 \mathrm{D}$ images, which could complete the online databases such as InsideWood (http://insidewood.lib.ncsu.edu/search) and wood anatomy of Central European species (http://www.wsl.ch/land/products/dendro). At last, once the substrate is virtualized, all kinds of manipulation are feasible. The X-ray sub-micron tomography equipment presented in this paper will be a valuable tool in material and life sciences in general.

\section{Acknowledgements}

The authors owe their gratitude to Frederico D'Almeida for the non-linear diffusion toolbox, Ignacio Larrabide for the topological image segmentation algorithm, Jelle Vlassenbroeck for help with Morpho+ and Yoni De Witte for help with the Octopus 3D Viewer. Furthermore, the authors express their gratitude to the anonymous reviewers for their contribution. Finally, the authors wish to thank the Fund for Scientific Research-Flanders (Belgium) for the postdoctoral funding granted to the first author.

\section{References}

Badel E., Delisee C. and Lux J., 2008. 3D structural characterisation, deformation measurements and assessment of low-density wood fibreboard under compression: the use of x-ray microtomography. Compos. Sci. Technol. 68: 1654-1663. 
Boone M., De Witte Y., Dierick M., Van den Bulcke J., Vlassenbroeck J. 379 and Van Hoorebeke L. (2009). Practical use of the Modified Bronnikov 380 Algorithm in micro-CT. Nucl. Instrum. Methods Phys. Res. Sect. B: Beam 381 Interact. Mater. At. accepted.

Cnudde V. and Jacobs P.J.S., 2004. Monitoring of weathering and conservation of building materials through non-destructive X-ray computed microtomography. Environ. Geol. 46: 477-485.

Coyle H.M., Ladd C., Palmbach T. and Lee H.C., 2001. The green revolution: Botanical contributions to forensics and drug enforcement. Croat. Med. J. 42: 340-345.

De Vetter L., Cnudde V., Masschaele B., Jacobs P.J.S. and Van Acker J., 2006. Detection and distribution analysis of organosilicon compounds in wood by means of SEM-EDX and micro-CT. Mater. Char. 56: 39-48.

Fonti P., Solomonoff N. and Garcia-Gonzalez I., 2007. Earlywood vessels of Castanea sativa record temperature before their formation. New Phytol. 173: $562-570$.

Fu D.S. and Kuduvalli G., 2008. A fast, accurate, and automatic 2D-3D image registration for image-guided cranial radiosurgery. Med. Phys. 35: 2180-2194.

Fuchs A., Schreyer A., Feuerbach S. and Korb J., 2004. A new technique for termite monitoring using computer tomography and endoscopy. Int. J. Pest Manage. 50: 63-66.

IAWA Committee, Richter H.G., Grosser D., Heinz I. and Gasson P.E., 2004. IAWA list of microscopic features for softwood identification. IAWA J. 25: 1-70.

IAWA Committee, Wheeler E.A., Baas P. and Gasson P.E., 1989. IAWA list of microscopic features for hardwood identification. IAWA Bull. 10: 219332.

Knapic S., Louzada J.L., Leal S. and Pereira H., 2007. Radial variation of wood density components and ring width in cork oak trees. Ann. For. Sci. 64: 211-218.

Larrabide I., Feijóo R.A., Novotny A.A. and Taroco E.A., 2008. Topological derivative: A tool for image processing. Comput. Struct. 86: 1386-1403. 
422 Lee S.J. and Kim Y., 2008. In vivo visualization of the water-refilling

423 process in xylem vessels using X-ray micro-imaging. Ann. Bot. 101: 595-

424602.

425

426

427

428

429

430

431

432

433

434

435

436

437

438

439

440

441

442

443

444

445

446

447

Limaye A., 2006. Drishti - Volume Exploration and Presentation Tool. Visualization Conference, Baltimore, USA.

Macchioni N., Palanti S., Rozenberg P., 2007. Measurements of fungal wood decay on Scots pine and beech by means of X-ray microdensitometry, Wood Sci. Technol. 41: 417-426.

Makinen H., Jyske T. and Saranaa P., 2008. Variation of tracheid length within annual rings of Scots pine and Norway spruce. Holzforschung 62: 123-128.

Masschaele B.C., Cnudde V., Dierick M., Jacobs P., Van Hoorebeke L., Vlassenbroeck J., 2007. UGCT: new X-ray radiography and tomography facility, Nucl. Instrum. Methods Phys. Res. Sect. A: Accel. Spectrom. Detect. Assoc. Equip. 580: 266-269.

Park W.-K., Telewski F.W., 1993. Measuring maximum latewood density by image analysis at the cellular level. Wood Fiber Sci. 25: 326-332.

Philippe M. and Bamford M.K., 2008. A key to morphogenera used for Mesozoic conifer-like woods. Rev. Palaeobot. Palynol. 148: 184-207.

Reme P.A., Helle T., 2002. Assessment of transverse dimensions of wood tracheids using SEM and image analysis, Holz Als Roh-und Werkst. 60: 277-282.

Schweingruber F.H., 1990. Anatomy of European woods. Paul Haupt Berne and Stuttgart Publishers, Stuttgart.

Steppe K., Cnudde V., Girard C., Lemeur R., Cnudde J.P. and Jacobs P., 2004. Use of X-ray computed microtomography for non-invasive determination of wood anatomical characteristics. J. Struct. Biol. 148: 1121.

Taina I.A., Heck R.J. and Elliot T.R., 2008. Application of X-ray computed tomography to soil science: A literature review. Can. J. Soil Sci. 88: 1-20.

Tomazello M., Brazolin S., Chagas M.P., Oliveira J.T.S., Ballarin A.W., Benjamin C.A., 2008. Application of X-ray technique in nondestructive evaluation of eucalypt wood, Maderas-Cienc. Tecnol. 10, 139-149. 
467 Trtik P., Dual J., Keunecke D., Mannes D., Niemz P., Stahli P., Kaestner 468 A., Groso A. and Stampanoni M., 2007. 3D imaging of microstructure of 469 spruce wood. J. Struct. Biol: 159, 46-55.

470

Van den Bulcke J., Masschaele B., Dierick M., Van Acker J., Stevens M. and Van Hoorebeke L., 2008. Three-dimensional imaging and analysis of infested coated wood with X-ray submicron CT. Int. Biodeterior.

474 Biodegradation 61: 278-286.

475

476 Vlassenbroeck J., Dierick M., Masschaele B., Cnudde V., Van Hoorebeke

477 L. and Jacobs P., 2007. Software tools for quantification of X-ray 478 microtomography at the UGCT. Nucl. Instrum. Meth. Phys. Res. 580: 442479445.

480

Wagenführ R., 2007. Holzatlas, Fachbuchverlag Leipzig, Leipzig.

Wagenführ R. and Schreiber C., 1989. Holzatlas, 3rd ed. VEB Fachbuchverlag Leipzig, Leipzig.

Wang Y., Muszynski L. and Simonsen J., 2007. Gold as an X-ray CT scanning contrast agent: Effect on the mechanical properties of wood plastic composites. Holzforschung 61: 723-730.

Wildenschild D., Hopmans J.W., Vaz C.M.P., Rivers M.L., Rikard D. and Christensen B.S.B., 2002. Using X-ray computed tomography in hydrology: systems, resolutions, and limitations. J. Hydrol. 267: 285-297. 


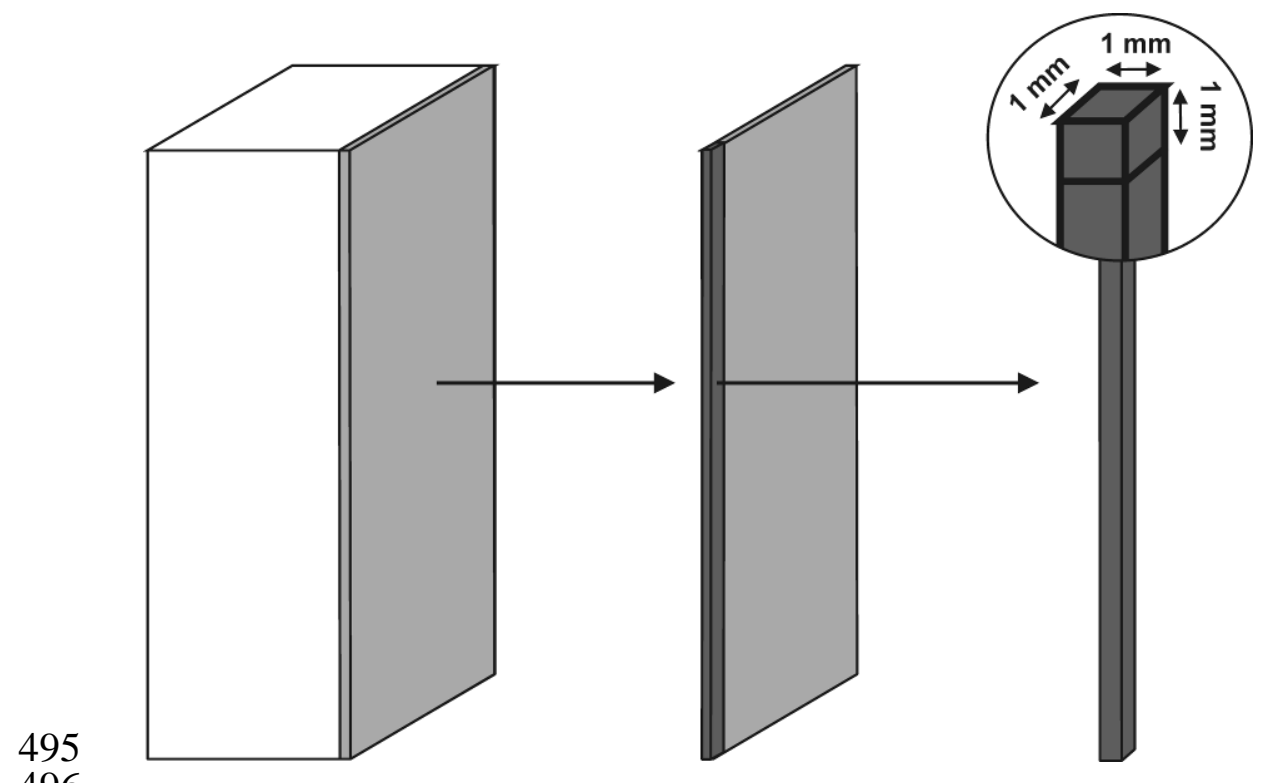

496

497

Fig. 1. Sample preparation for X-ray scanning.

498 


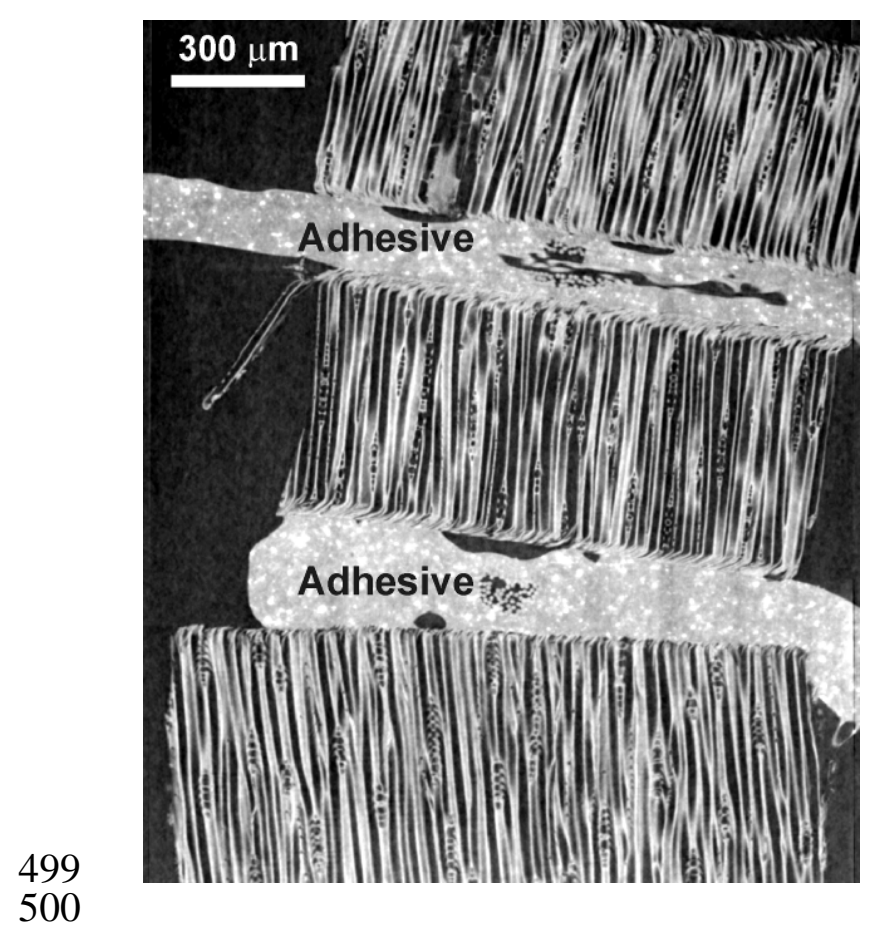

501 Fig. 2. Cross-sectional view through a stack of three pine latewood 502 samples.

503 

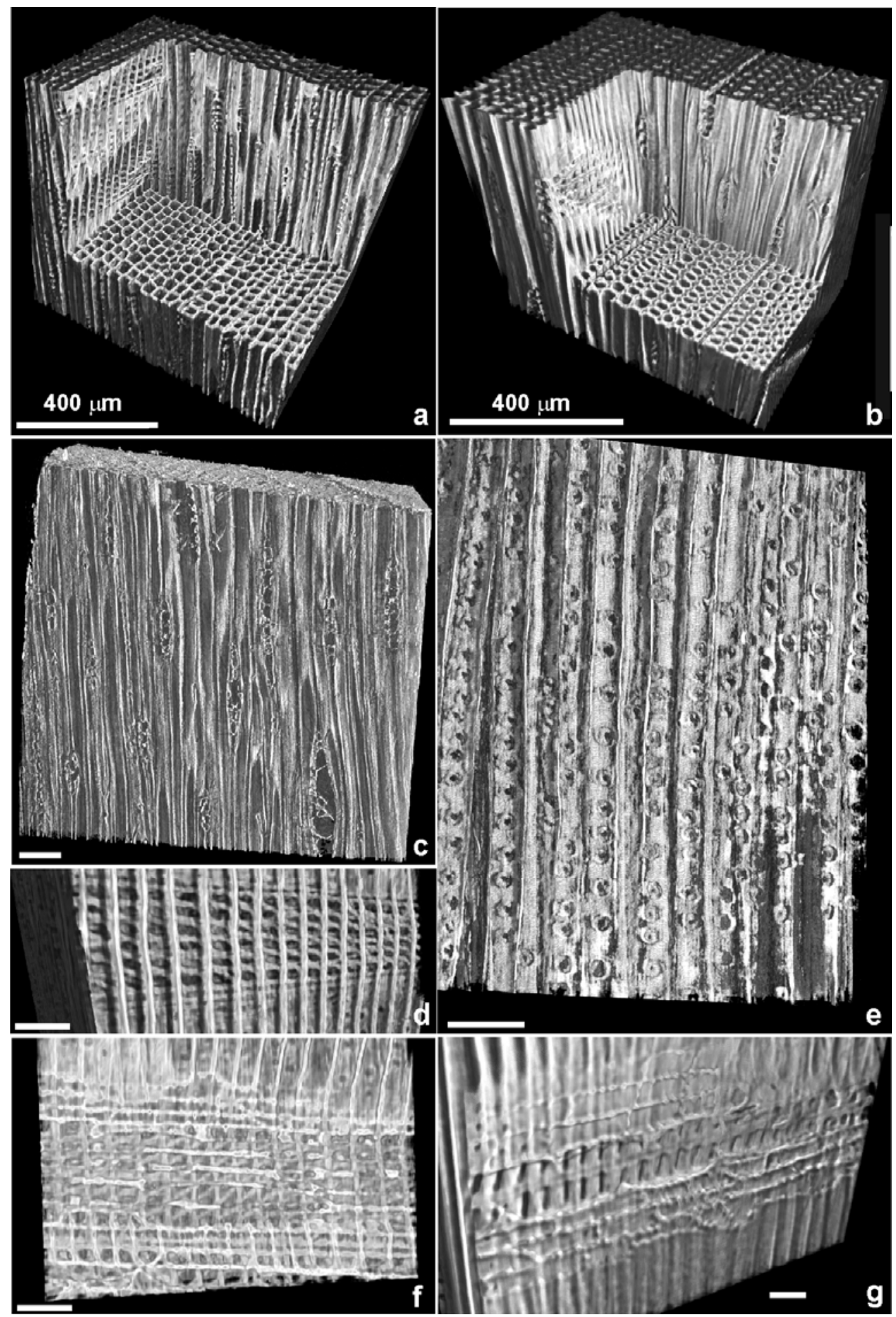

505

Fig. 3. Overview with cut out giving a clear view on the internal anatomy of 508 with limited height; (d) fenestriform cross-field pitting; (e) uniseriate pitting 509 of cell walls of tracheids; $(\mathrm{f}+\mathrm{g})$ dentation of cell walls adjacent to ray 510 parenchyma. White bar $=100 \mu \mathrm{m}$. 


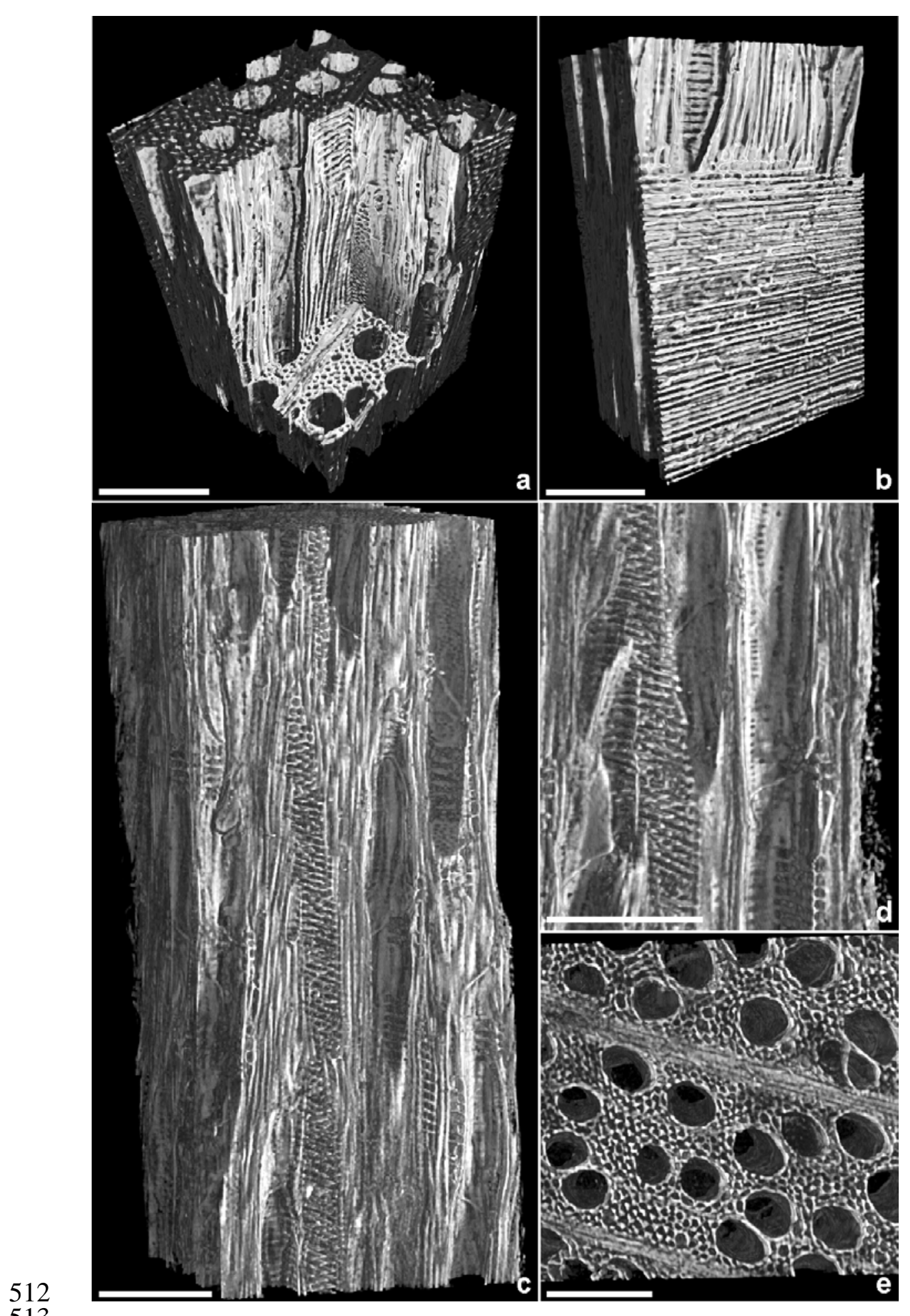

514 Fig. 4. Overview with cut out (a) giving a clear view on the internal 515 anatomy of Fagus sylvatica L.; (b) rays and scalariform vessel-ray pitting; 516 (c) large rays with several vessel cross-sections; (d) perforations of the 517 vessel wall and view on the ray frame; (e) top view. White bar $=200 \mu \mathrm{m}$. 


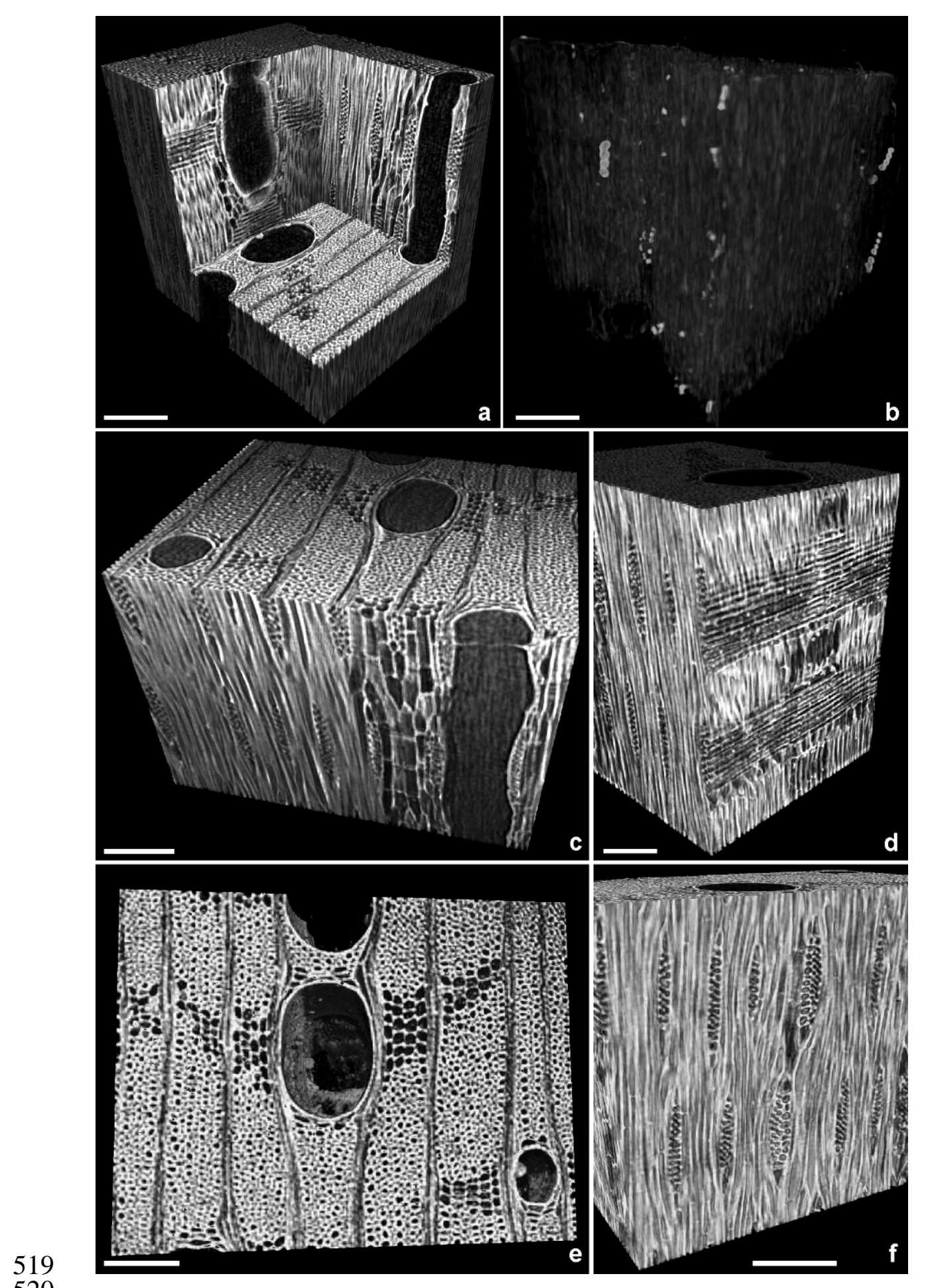

521 Fig. 5. Overview with cut out (a) giving a clear view on the internal 522 anatomy of Disthemonanthus benthamianus Baill.; (b) prismatic crystals; 523 (c) parenchyma, rays and slice through vessel; (d) longitudinal slice 524 through rays; (e) top view; (f) tangential view on rays. White bar $=200 \mu \mathrm{m}$. 


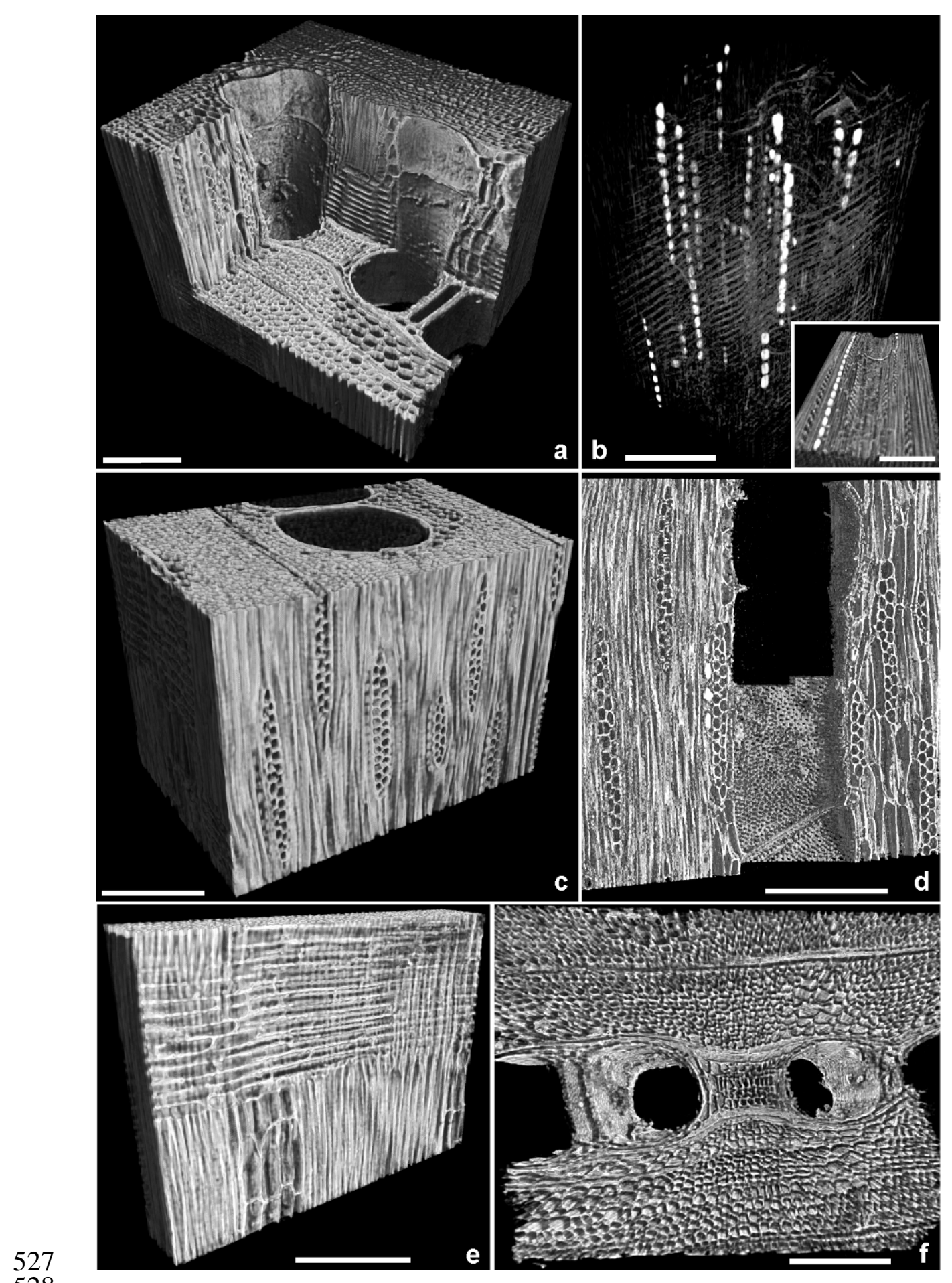

529 Fig. 6. Overview with cut out (a) giving a clear view on the internal 530 anatomy of Afzelia bipindensis Harms; (b) prismatic crystals; (c) rays; (d) 531 simple vessel perforation; (e) view through ray and parenchyma; (f) top 532 view. White bar $=200 \mu \mathrm{m}$. 
A

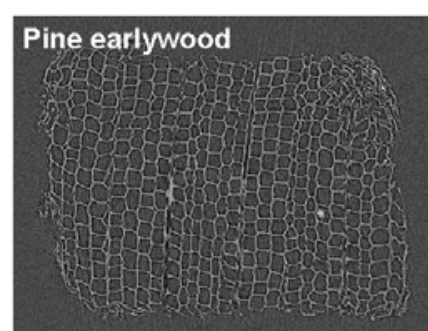

Pinelatewood

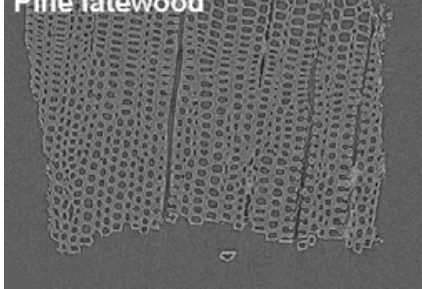

Beech

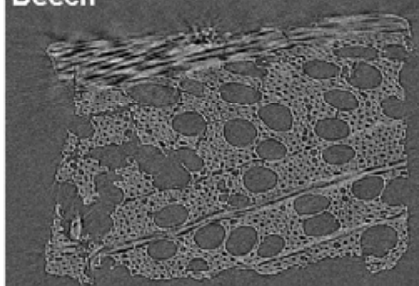

Movingui

534

535

536

537
B
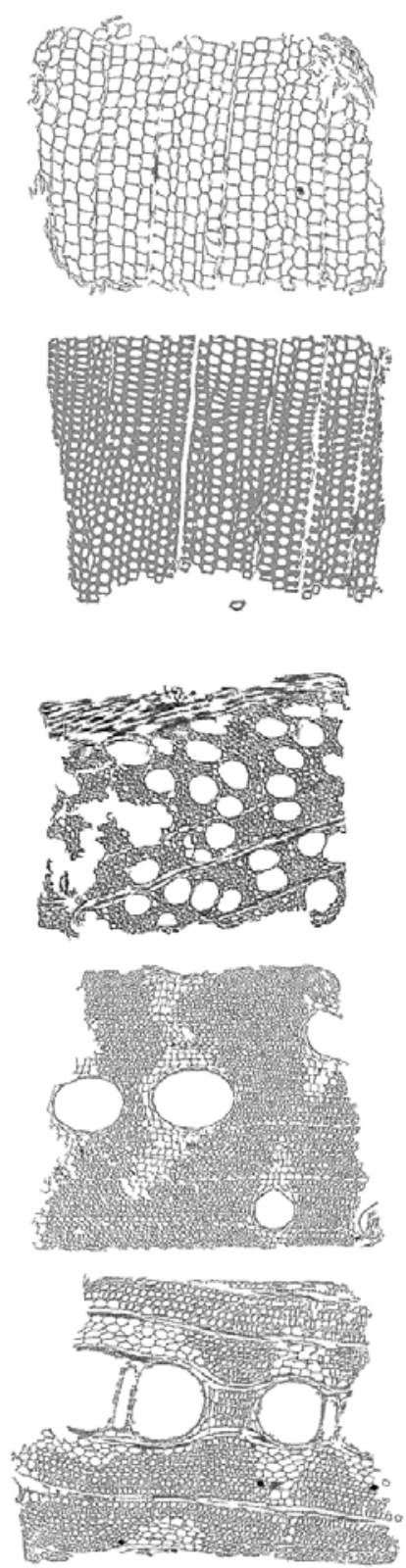

C
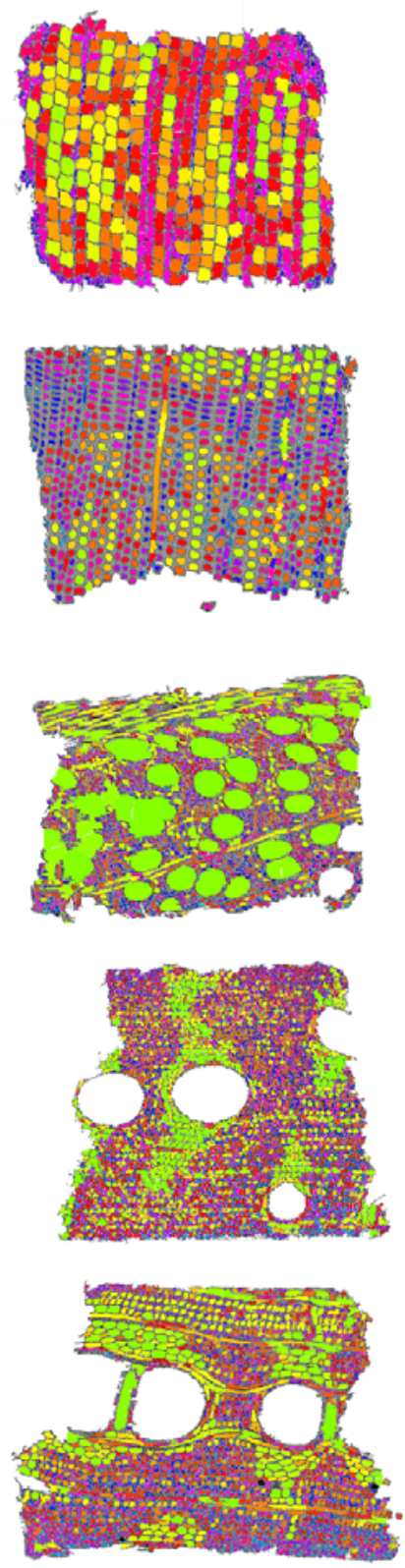

Fig. 7. Original (A), noise-free (B) and segmented (C) images. 


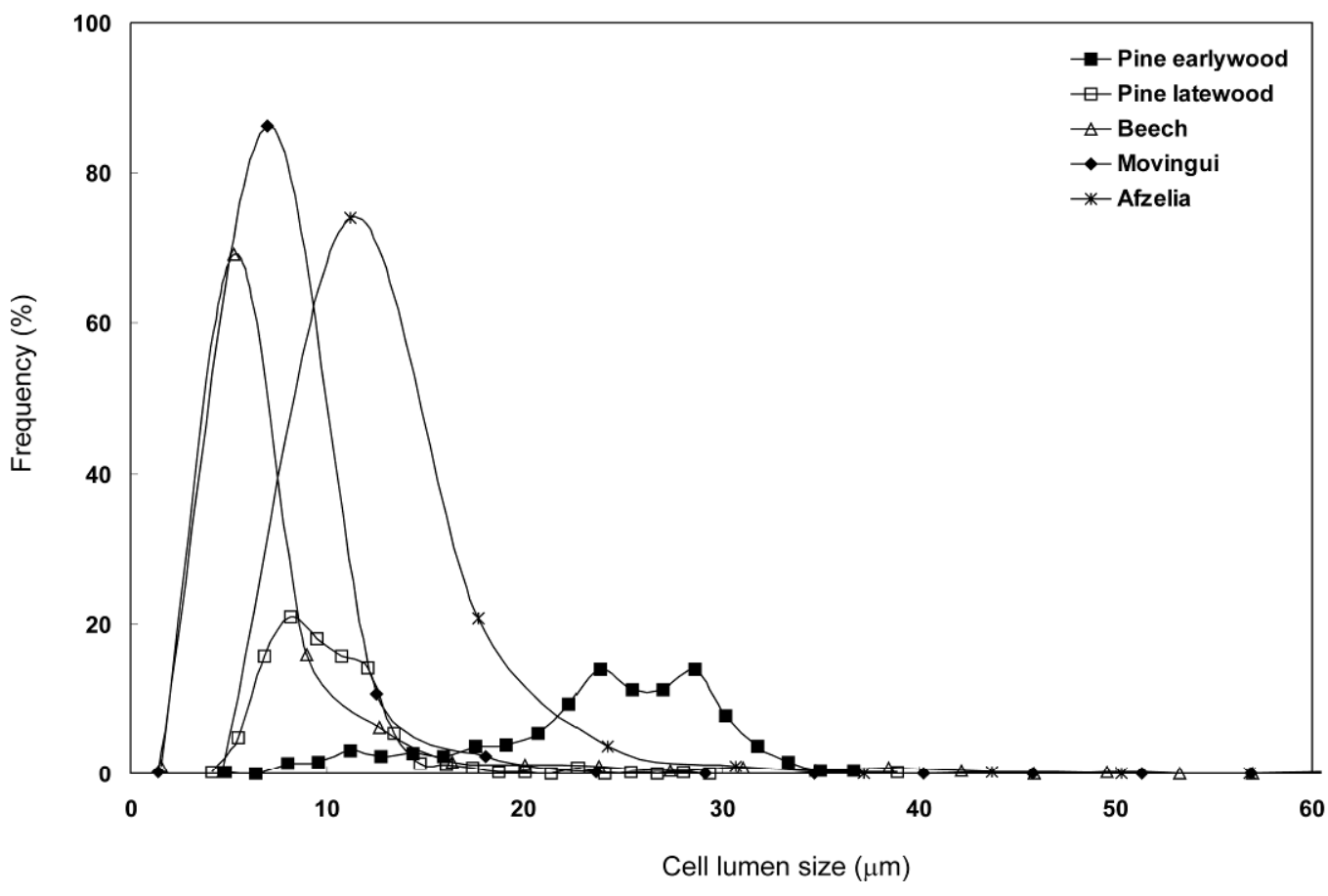

540 Fig. 8. Frequencies of the equivalent diameter of the cell lumen sizes for 541 four wood species.

542

543

544 


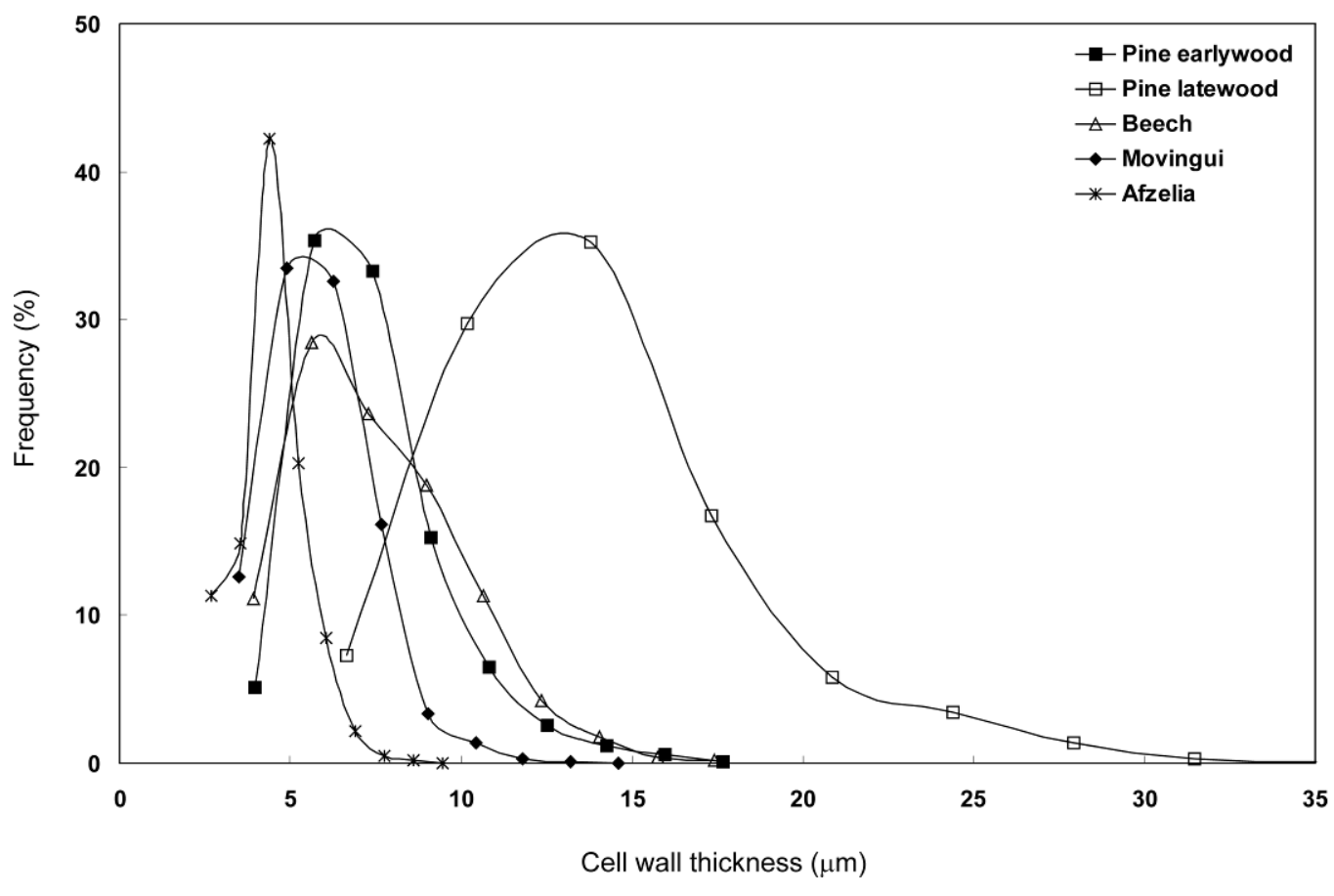

545

546

547

548

Fig. 9. Frequencies of cell wall thicknesses for four wood species. 
a

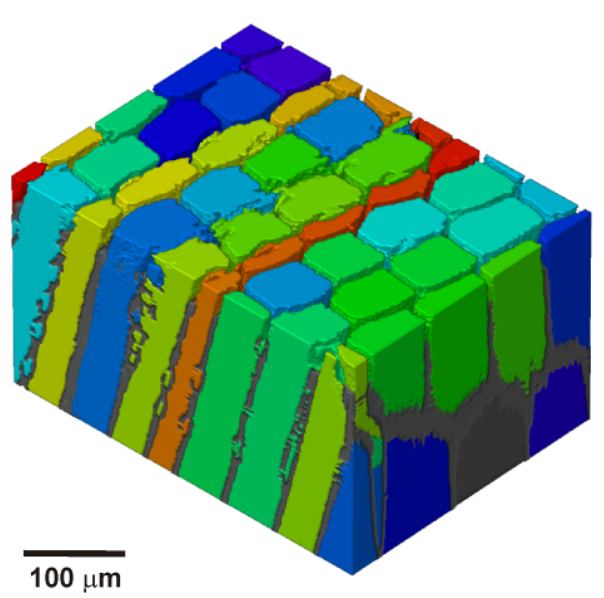

b

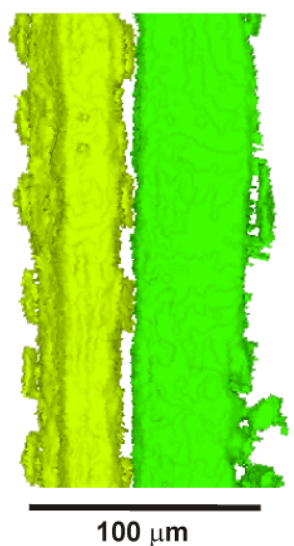

c

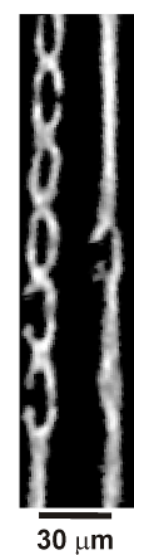

Fig. 10. Labelled cell lumens of the noise-free pine earlywood sample with 553 greyish cell wall (a), detailed rendering of pitting between two cells (b) and $5542 \mathrm{D}$ slice as an example of the limits of resolution for pit visualization. 

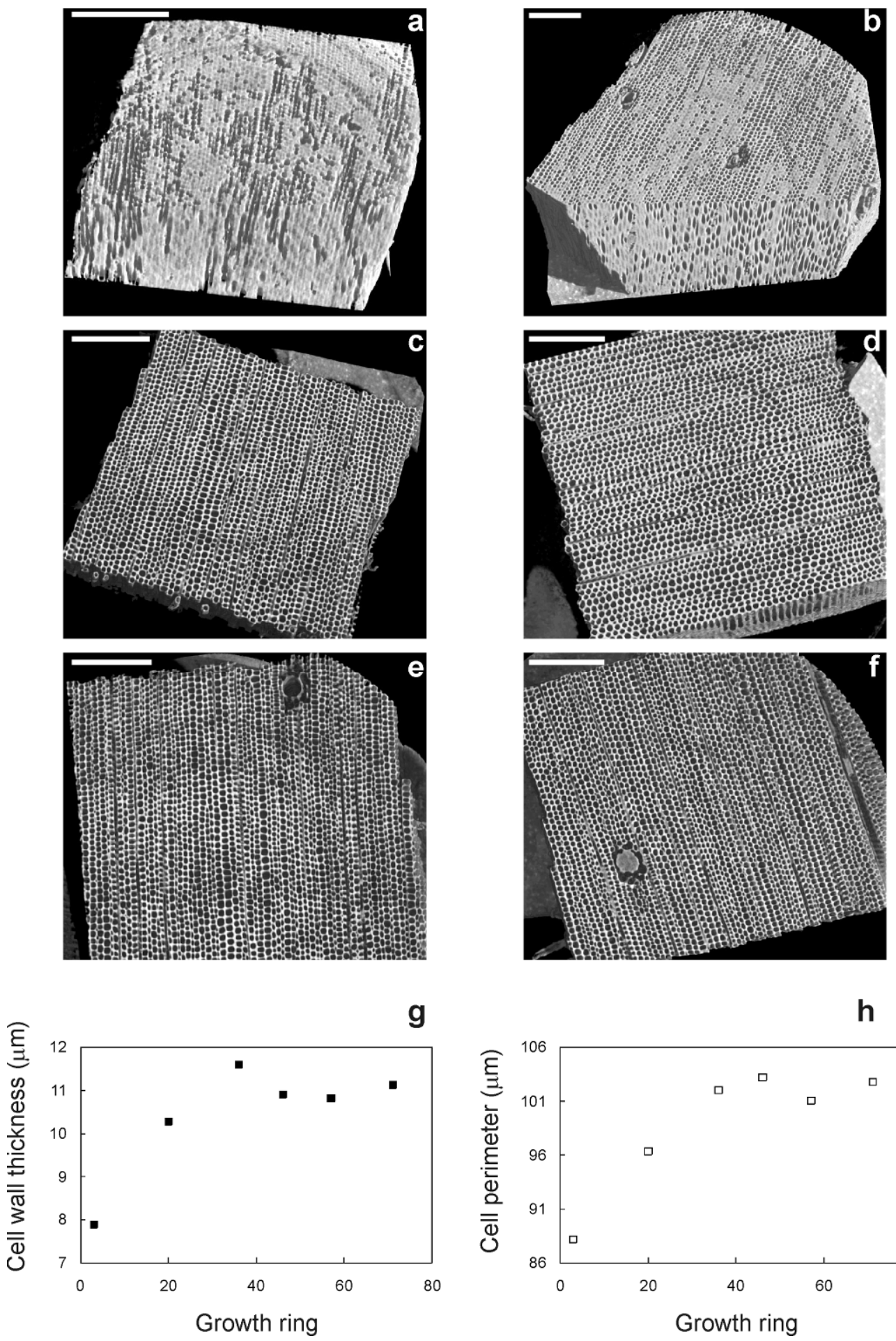

h

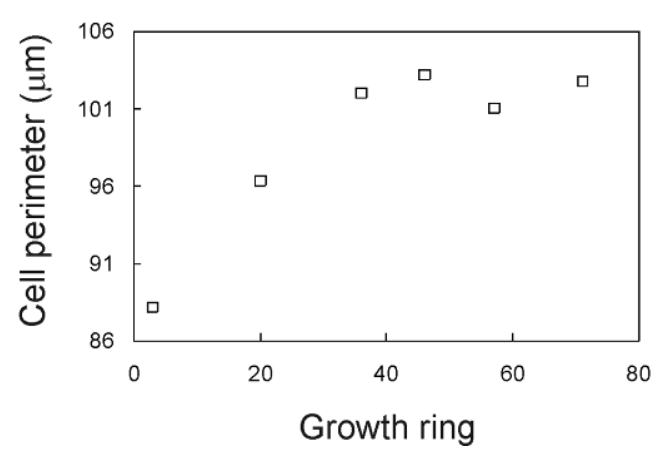

559 Fig. 11. Six reconstructed pine latewood volumes sampled from pith to 560 bark (a-f) and their cell wall thickness $(\mathrm{g})$ and cell perimeter $(\mathrm{h})$ in function 561 of the growth ring they were sampled from. White bar $=400 \mu \mathrm{m}$. 